\title{
Discourse Power as a Means to 'Struggle for Position': a Critical Case Study of the Belt and Road Narrative's Effects on Foreign Policy Formulation in the Netherlands
}

\begin{abstract}
This article investigates China's use of strategic narratives to facilitate its geopolitical return, through a critical case study of the Belt and Road narrative's effects on foreign policy formulation in the Netherlands. Departing from postmodern critiques of the traditional Western approach to soft power and Chinese elites' conceptualization of the Belt and Road as a means to contest the West's discursive hegemony, it initially proposes a theoretical framework meant to identify co-optive processes resulting from the narrative's reception. It subsequently tests this framework, which combines the strategic narrative strand of constructivist soft power theory with Gallarotti's concept of 'bargaining spaces' to structure the analysis, on the the Netherlands' in the context of its recent revision of its China policy. By connecting elements of the narrative with co-optive processes found to occur within three subnational cohorts (business, media ecology, and foreign policy establishment), it highlights that Western countries may be more susceptible to non-coercive Chinese influence than is conventionally thought. In terms of a theoretical contribution, the article demonstrates that a decentred and outcome-oriented approach to narratives like the Belt and Road may enhance understanding of the mechanisms underlying China's ability to use rhetorical strategy to tilt political battlefields to its favor.
\end{abstract}

Keywords Belt and Road Initiative, Sino-Dutch relations, Soft power, Strategic narratives, Chinese official discourse.

\section{Introduction}

China's growing ambitions for promoting its own vision of international cooperation, exemplified by President Xi Jinping's 2017 speech at the $19^{\text {th }}$ National Congress of the Communist Party of China (CPC) [67], have frustrated hopes in the West for China's integration into the liberal world order. In the Netherlands -which strongly identifies as a promoter of 'universal values' but is also China's eighth largest trade partner- the reality of a China un-socialized is forcing a re-evaluation of the 'socialization-paradigm' which shaped Western imaginaries of China's rise since the start of its reform and opening up [68]. ${ }^{1}$ Few instances better illustrate the consequences of this juncture than the Dutch governments' new China-strategy, which was adopted in May of 2019. ${ }^{2}$ Although presented as a 'more realistic' and interest-based take on Sino-Dutch relations, its non-committal and sometimes contradictory tone suggests it was in fact the result of a complex balancing act between competing pressures [35]. Even more surprising, some of its elements, such as its implicit recognition of the existence of a distinct set of Chinese values and its emphasis on more European Union (EU) cooperation on foreign policy, respectively benefit China and contradict the Netherlands' traditional foreign policy identity [12]. In its response to the document, The Dutch Advisory Council for International Affairs (AIV) alluded to these contradictions by noting that 'strategic dilemma's' in the relationship with China require the country to carefully consider 'what it stands for and what it is prepared to do to protect this, including in the public debate' ([1]: 83). However, it neither question the origins of these dilemma's, nor takes into account China's role in co-producing this state of affairs.

\footnotetext{
${ }^{1}$ According to the socialization-paradigm, economic engagement and the growth of the middle class and civil society would naturally result in socio-political reforms $[8,68]$.

${ }^{2}$ The new strategy was requested in May of 2018 as a replacement for the 2013 China-note "Investing in Values and Business".
} 
While the AIV's assumption of a straightforward societal 'China-debate' is problematic, given the substantial evidence that China actively pursues policies for shaping discourse about itself abroad, it is not entirely surprising [33]. After all, the traditional neoliberal approach to soft power developed by Nye, which argues that China's 'ability to get what it wants through attraction rather than coercion or payment' is hindered by the disparity between 'universal' and Chinese values, is widely internalized in Western policy circles [16, 43, 46, 47]. ${ }^{3}$ Despite the prevalence of this interpretation, there are powerful theoretical and empirical arguments against its validity. In terms of theory, critical scholars argue that the 'Nyesian' approach includes methodological and normative assumptions which tend to engender Eurocentric conclusions grounded in the value-complex underlying neoliberal international relations theory, rather than observation $[31,20,64] .{ }^{4}$ In terms of empirical black swans, the curious shifts in the Dutch China-strategy are complemented by recent instances of unexpected Chinese soft power success in Europe through its Belt and Road (B\&R), the global infrastructure investment framework at the centre of Xi's foreign policy agenda [71].

Since its announcement in 2013, the B\&R has elicited an rich academic debate on its significance for China's influence in Europe and in the world, and a range of interpretations which -depending on their theoretical grounding- reinforce or contest the Eurocentric bias to China's ability to co-opt policymaking abroad. Until 2017, the literature featured mostly material-cum-geopolitical approaches [7, 23, 34, 45], and analyses of the role of the nexus between China's domestic and foreign policies for the B\&R's development $[4,24,56,70]$. The range of interpretations, from Holslag's 'offensive mercantilist effort for securing Europe's markets' [23], to Huang's 'comprehensive attempt to sustain economic development and provide important economic public goods' [24], provided important insights into China's ability to shape global economic structures and alleviate domestic problems such as overproduction and uneven development through the B\&R. Despite Chinese leaders' emphasis on initiatives like the B\&R as a means to improve 'discourse power' (话 语权) and contest the 'West's discursive hegemony’ (西方话语霸权) [13, 28, 74], the B\&R's non-material potentialities only started to be seriously examined by postmodern scholars after 2016 [25, 27, 32, 42, 60]. This body of work contains equally varied views, ranging from the B\&R's as a 'desecuritisation narrarive' [25] to 'a means for decolonizing global ideational structures' [32].

Although such 'decentred' accounts proved instrumental for contextualizing the project's ideational dimension within historical processes of China's outward discursive engagement and drawing attention to the importance Chinese elites attach to it, there have been few empirical analyses of its non-material effects. Given China's proven ability to use the B\&R to co-opt European member states (EUMS) and thus reinforce intra-EU divisions on important policy issues, a decentred analysis of its effects would lend valuable insights for a coherent European response and an understanding of China's co-optive effors which is not based on a seriously flawed theoretical framework. ${ }^{5}$

This article seeks to contribute to such an understanding through a critical case study of the B\&R's cooptive effects on the Netherlands' formulation of its China policy between May of 2018 and July of 2019. In order to answer the question how the $\mathrm{B} \& \mathrm{R}$ provides China with non-coercive influence in a particular country, the article proposes a theoretical framework which integrates insights from the decentred $B \& R$ literature with insights from the theoretical literature on soft power. Specifically, it builds on Lams' [27] and Zeng's [72] reinterpretation of the $B \& R$ as a 'strategic narrative' to guide the identification of co-optive effects. It subsequently introduces Gallarotti's 'bargaining space' concept to structure the case study into subnational networks of relationships which may be influenced to affect foreign policy outcomes, and thus mitigate the

\footnotetext{
${ }^{3}$ Also supported by author interviews with a senior policy officer at the Dutch Ministry of Foreign affairs, phone interview, April 2018; a scholar involved in policy consultation, The Hague, August, 2018; and member of the Parliamentary Commission of Foreign Affairs, The Hague, April 2019.

4 'Nyesian' is used here to denote analyses based on Nye's soft power framework, and includes instances wherein scholars have modified the framework within the boundaries of the assumptions on which it is based.

${ }^{5}$ Examples of this ability are Greece's role in preventing a critical EU statement on the South China Sea Arbitration in 2016, and Italy's signing of a Belt and Road Memorandum of Understanding in March of 2019 [71].
} 
indeterminacy of cause and effect $[16,37]$. The decision to take the Netherlands as a critical case for the application of this framework is based on the purported contrast between Chinese and Dutch values, which is theorized to hinder the internalization of the B\&R's constituent discourses, and the country's relationship with the B\&R. Furthermore, its dependence on its role as a major transportation hub and substantial economic ties to China make it likely that Dutch society will be attuned to the narrative, while the absence of B\&R-labeled investments decreases the likelihood that observed effects are the result of inducement [3]. Although other rich EUMS like France, the United Kingdom, Germany, Belgium, or Sweden share these criteria to some degree, the revision of the Dutch China-strategy between May of 2018 and May of 2019 entailed unique opportunities for identifying actors and case characteristics.

This article consists of four parts. The first part introduces the proposed theoretical framework. The second part details the critical within-case methodology and the methods of data collection and analysis. It also identifies three distinct cohorts, the media ecology, business, and foreign policy establishment, as actors within the national bargaining space which merit attention. The third part contains the analysis and is divided into two main steps, which aim to test the framework's predictive and explanatory power respectively. The first step hypothesizes the B\&R narrative's effects, based on a comparison of the narrative's formulation and projection with the characteristics of the Dutch case and its constituent cohorts. The second step tests these hypotheses through an analysis of the narrative's reception in each cohort. The conclusion tentatively compares findings across other EUMS, evaluates the framework's use, and provides suggestions for further research.

\section{Soft power, Strategic Narrative Theory and the Bargaining Space Concept}

Through a discussion of contemporary criticism of the traditional approach to China's soft power, this section elucidates the benefits of a decentred and narrative-based approach towards effectively conceptualizing the B\&R's non-material dimension. It subsequently introduces the bargaining space concept.

The traditional resource-centred approach to soft power left a distinct mark on Western views of China's soft power. Throughout the early 2000's, scholars within this body of research conducted empirical analyses in an attempt to 'measure' China's soft power on the basis of data such as opinion polls, the number of international exchange students and investment in broadcasting capabilities [5, 9, 10, 18, 29, 43, 44]. Broadly speaking, they conclude that Chinese soft power is fundamentally flawed, due to the limited attractiveness of its values, its self-centred foreign policy behaviour and the contradictions in its domestic and international communication. From this perspective, the country's success in improving ties with key interlocutors through the Belt and Road Forum (BRF) and amassing substantial international support for its Xinjiang-policy are assumed to be outliers, or the result of economic inducement [48]. ${ }^{6}$

Critics of this 'Nyesian' approach provide a two-sided explanation for the existence of this Eurocentric bias. Firstly, Mattern argued that Nye's assumption that 'universal' values inherently attract leads to a mixed ontological status for attraction, as both "an essential condition [...] and a result of social interaction" ([31], 591). ${ }^{7}$ This prescriptive reading of soft power not only affects Western views of China's soft power, but also forces states like China and Russia to re-conceptualize soft power to adjust it to their national context [64]. Hayden illustrated how the resulting conceptual divergence between Western and Chinese soft power (termed 'cultural soft power' by Chinese leaders and scholars) leads to a divergence between practices of outward discursive engagement and public diplomacy $[22,46]$, which in turn leads to mutual perception of soft power initiatives as ideological threats [64]. Secondly, critics argue that the traditional approach implicitly bypasses the relational dimension of power, as it downplays the subnational relationships which inform policy

\footnotetext{
${ }^{6}$ The emergence of the 'sharp power' concept serves as a reminder of the political value attached to the soft power concept by neoliberal policy-elites [62].

${ }^{7}$ Nye explicitly lists cosmopolitanism, democracy and peace as universally attractive values ([43]: 11).
} 
formulation in favour of presenting clear-cut evaluations of a country's net national soft power [5, 53]. Motivated by the theory's inability to connect soft power efforts to effects, critics (Nye himself included) have called for issue-specific analyses which may improve inferences about the relationship between soft power sources and policy outcomes [44].

Strategic narrative theory represents one such attempt to centre the analysis on actions and outcomes, by anchoring soft power analysis in a constructivist epistemology [36]. By defining strategic narratives like the $\mathrm{B} \& \mathrm{R}$ as a "communicative tool through which political actors [...] attempt to give determined meaning to past, present and future in order to achieve political objectives", Miskimmon et al combine a Foucauldian understanding of discourse with a profound sensitivity to the consequences of the information revolution ([36], 7-10). According to strategic narrative theory, the B\&R's discursive dimension may exercise power over the behaviour of actors (audiences) through persuasion and "by constituting the experience of international affairs and thus the identity of its actors and the meaning of the system" ([36], 26). Strategic success is thus defined by an actor's ability to create this meaning for others, by effectively dominating fields of discourse through propagation of its own narrative and the exclusion of alternative accounts. The main benefit of this approach when compared to public diplomacy or traditional soft power is that its ontology of soft power requires cooptive processes (through which an actor's experience of the international in reconstituted) to be identified inductively, which accounts better for the complexity of context-heavy relationships [16]. Moreover, the theory is suited to issue-specific analyses, as it puts into focus processes of narrative formulation and projection on the Chinese side, and subsequent translation and reception on the receiver's side [53].

Miskimmon et al identified various issues which hamper the identification of causal paths between narratives and their effects on audiences [37]. Chief among these are the impossibility of perfect communication and the complexity of relationships within social structures. While the first may be ameliorated by including the media ecology which surrounds a case and other mediating factors in the analysis, the second issue necessitates the establishment criteria for determining which actors and relationships matter. Feklyunina notes that besides a priori identities, audiences' ability to affect foreign policy making in a target country should guide empirical inquiry [14]. These two criteria only partly control for complexity however, as the results of policymaking processes are also highly contingent on how actors use these abilities and how their narrative-induced actions affect all other actors within and across decision-making processes. Thus, controlling for what Gallarotti defined as 'the manifold consequences for any action or policy generated by indirect and feedback effects' and agency is not simply a matter of electing thick over thin analysis [16].

One way to control for such reflexive behaviours is by mapping domestic actors (or groups) who fulfil the first two criteria onto a national 'bargaining space', where the status quo at a particular point in time represents that state's complex identity (and thus interests) vis-à-vis the narrating actor [16, 63]. The status quo can be conceptualized as the continuum of conceivable policy options, as determined by the space's 'bargaining boundaries'. These are subject to constant renegotiation by domestic actors, who occupy 'bargaining positions', as determined by their identity and ability to shape policy. This process of renegotiation is subject to foreign interference spanning the entire threat-persuasion spectrum, including the use of strategic narratives to reshape identities. Provided that the analysis is sufficiently context-sensitive, the bargaining space framework improves the inductive identification of co-optive processes, as it enables the researcher to connect changes in the bargaining positions of actors to their reception of the narrative, examine the process of renegotiation, and establish whether this has led to a change in the space's status quo. Practically this is done by examining to what extent an actor has internalized the various discourses contained by the narrative, and how this shaped their interactions with the policy process. Finally, care has to be taken to eliminate alternative (non-discursive) explanations for an actor's behaviour.

\section{Methodology and Data}


To understand how the B\&R strategic narrative provides China with influence in the Dutch bargaining space, the analysis needs to include China's intentions, the narrative's power sources (its constituent discourses and utilized transmission strategies) and outcomes in an integrative manner [5]. Therefore, the critical case study was designed as a holistic 'issue-specific' analysis, consisting of a constellation of relationships in the context of the Sino-Dutch relationship [57, 69]. Although data was mainly gathered between May of 2018 and July of 2019 , the period wherein the China policy was formulated and made public, the temporal bound was extended to the B\&R's announcement in 2013 to cover long-term effects. Following an exploratory analysis, three cohorts with distinct identities, capabilities and positions within the national bargaining game -the media ecology, business elites and foreign policy establishment- were identified. ${ }^{8}$ The theoretical framework was subsequently applied in two steps, meant to evaluate its predictive and explanatory power $[17,69]$. The first step hypothesized the narrative's effects, based on a theory-informed comparison between China's intentions and the contents of the B\&R narrative, and the characteristics of Dutch case and its constituent cohorts. The second step tested these hypotheses per cohort, and compared findings to answer the research question.

Data selection and analysis were tailored to the requirements of both steps and the characteristics of individual cohorts, with triangulation as priority. ${ }^{9}$ For the first step, official documents served as a benchmark for China's goals and the narrative's contents. Characteristics of the Dutch case and its cohorts were based on a selection of policy papers about the Sino-Dutch relationship and official documents. For the second step, a balance was struck between the representativeness of the data for each cohort and the ability to triangulate findings across cohorts. The narrative's effects on the media ecology were measured through a mixed content and discursive analysis of 135 newspaper articles from five quality newspapers (Trouw, de Volkskrant, NRC Handelsblad and Financieel Dagblad) and two popular newspapers (AD, Telegraaf) published between 2013 and July of 2019. Media sources were chosen based on the size of their circulations and variety in ideological background to provide the broadest possible evaluation, while only articles which contained at minimum a paragraph on the topic were included. The selected articles were then coded inductively in two stages, on general tone (positive, negative and neutral), and subject matter (such as 'disruption of EU unity' and 'effects on the Dutch economy'). Each stage consisted of multiple coding passes.

The second and third cohorts, comprised of business elites and the foreign policy establishment respectively, were analysed using official documents, semi-structured elite interviews and participant observation. Interviewed respondents were selected on the basis of their network, their knowledge of the B\&R, as well as their degree of interaction with the subject. Respondents from the foreign policy cohort consisted of ministerial experts, MP's with a seat on the Parliamentary Committee of Foreign Affairs (CFA), and academics who straddle the line between policy-making and policy input. Constant comparison of aspects of the narrative which featured in the experience of all three cohort with changes in their bargaining positions enabled inductive establishment of the narrative's soft power sources (defined as co-optive processes rather than 'resources') and tentative inferences about their effects on the national bargaining space. Finally, complementary participant observation allowed for up-close scrutiny and verification of these findings [54], and took place in The Hague during a conference about Chinese investments in December of 2018 and a conference on the China-note in June of 2019. A broad range of actors from all three cohorts were present at these events.

There are risks to using the above-mentioned methods to measure co-optive effects, chief among them the researcher's subjectivity and the need for sensitivity to context. ${ }^{10}$ Despite consciousness of this issue and the precautions made, these factors possibly had a role in highlighting some aspects to the detriment of others. Additionally, it is possible that the limited number of interviews has distorted the analysis. An attempt was

\footnotetext{
${ }^{8}$ The exploratory analysis consisted of desk-based investigation into the role of various stakeholders in previous policy processes, such as the formulation of the 2013 China-note.

${ }^{9}$ This is motivated by the need to eliminate alternative (non-discursive) explanations for behavioural change.

${ }^{10}$ The author had no professional or personal relationships with any of the respondents prior to this research.
} 
made to alleviate this by asking respondents to systematically compare their personal views with the views they encountered around them, to improve triangulation. Given the relatively dense nature of media, business and foreign policy networks in the Netherlands, these precautions were deemed to be able to safeguard the validity of the analysis. Further research will have to determine whether these measures can be applied as effectively across different cases.

\section{'Telling one's story well': the B\&R Narrative's Formulation, Projection and Predicted Reception}

A guiding principle for the formulation and projection of China's various narratives about its international reemergence is the CPC's functionalist interpretation of 'discourse power' (话语权), as a means to 'struggle for position' (争夺阵地) across domestic and international arenas and contest 'the West's discursive hegemony' (西方话语霸权) [27, 28, 65, 74]. ${ }^{11}$ This Marxist-Leninist informed interpretation of external communication as state-directed and whole-of-society action in combination with China's traditional holistic approach to foreign policy means its flagship narratives are characterized by substantial central oversight and shaped by an integration of domestic and international policy spheres. Reinforced by Xi Jinping's unusually strong hold on party politics and China's 'crossing the river by feeling the stones' approach to foreign policy concepts, these characteristics fundamentally shape the B\&R's formulation and projection $[6,73]$. Contrary to its first foray into the international discursive arena under Hu Jintao with the 'Peaceful Rise/Development' narrative, with which it reactively engaged the increasingly popular 'China threat' theory [74], the Belt and Road narrative represents an attempt to seize the discursive high-ground to redefine the international system and the identity of its occupants.

The B\&R narrative's formulation reflects both continuity and innovation in the changes to its external discursive engagement under Xi Jinping, as it complements the security-oriented national identity discoursecomplex of 'Peaceful Rise' with a vision for China's and the world's future. Explicit discourses such as 'winwin cooperation', talk of 'camel caravans and treasure loaded ships' and references to China's financial and political commitment to the project increase the audience's attention and inculcate the veracity of the narrative's implicit causal propositions [66]. These propositions are located at the intersection of what is said and not said, for instance when references to China's traditional culture are concealed by the linkage with the ancient silk roads. The primary causal proposition of the narrative frames China as the natural pivot of a common effort to 'manage the historical trend of globalization' by positioning the B\&R as an effective Chinese answer (中国方案) to 'a world fraught with challenges' [66]. Although the narrative has evolved over the years, this causal proposition was visible in the 'Visions and Actions' policy paper published by China's National Development and Reform Commission in 2015, and remains equally present in 2019's 'Progress, Contributions and Prospects' document published during the second BRF [39, 41].

In terms of projection, the narrative is mainly disseminated through events like the BRF, policy papers which are meant to 'explain' China's position and people-to-people (P2P) interactions, avenues which each serve specific functions in the 'struggle for position'. Ostentatious events like the BRF serve to improve China's image abroad and represent a strategic approach to drawing attention to the project in a heavily saturated global information environment [19]. Policy papers seem to be aimed at foreign elites and China watchers, in an attempt to rationalize China's policy to these audiences. Strong central oversight of the press and academia and economic incentives for domestic actors to 'toe the line' ensure that its projection extends into P2P interactions, thus enhancing the perception among audiences that the B\&R is based on substantial domestic support and represents a notable aspect of contemporary international politics.

\footnotetext{
11 The discourse power concept carries a connotation of discursive emancipation in Chinese, as is alternatively translated as 'the right to speak'.
} 
Upon closer examination, the benefits to the narrative's coherence and its pro forma internalization by domestic actors come with significant drawbacks. Firstly, contradictions between the project's execution on the ground and China's interest in maintaining the appearance of an undisputed 'win-win' success provide convenient ammunition for contestation of the narrative. The United States' use of China's controversial acquisition of Sri Lanka's Hambantota port to condemn the B\&R as a form of 'debt trap diplomacy' is arguably the most well-known example of this [38]. The experience which made this counter-narrative so potent was not that China practices systematic debt-trap diplomacy under the B\&R, but the sense that much of its lowerlevel workings are rather opaque and seem to produce results which contradict the lofty statements [15]. Moreover, in locales with strong suspicions of the CPC's international ambitions, the centralized telling of the B\&R story may reinforce audiences' view of the narrative as disingenuous or hiding ulterior motives [36].

Besides its formulation and projection, reception in the Dutch bargaining space is subject to a reception context consisting of two layers. The first layer consists of the balance between the country's self-identification as a promoter of human-rights and international trade in relation to historical experiences with Chinese pushback on values in the 1980's and 90's. In recent years, these experiences engendered an 'active but discreet' values-policy, which sought to avoid damage to the economic relationship. The perceived imbalance between values and trade in the relationship remains a contentious issue within the Dutch political space [1]. The second contextual layer can be summarized as insecurity regarding the ontological security of the liberal international order in the face of China's rise and the decline of multilateralism, and the country's limited ability to respond to these changes. The development of its new China-note, along with the promulgation of policy documents on topics such as state-based threats and industrial policy, are examples of its quest to bridge the widening gap between its foreign policy identity and new geopolitical realities [50]. ${ }^{12}$

Through comparison of the narrative's formation, projection and reception context with the a priori bargaining position of each cohort, the narrative's effects on the national bargaining space can be hypothesized. Firstly, the B\&R is likely to draw substantial attention in the Dutch media ecology, due to its sensational value and the anxiety about China's rise. Furthermore, the contrast between the positive image of China presented by the narrative and China-discourses which are present in this cohort means reception will likely be overwhelmingly negative. In terms of effects on the bargaining space, the narrative is predicted to increase the issue's salience and the political cost of entertaining a non-critical position on China. Secondly, the size, scope and prospects of the economic relationship and the domestic importance of the Dutch transport sector make it likely that the business cohort will be drawn to business-oriented parts of the narrative. As Dutch businesses are known for their a-political tendencies it is unlikely its implicit normative discourses will be actively contested, enabling a shift in the cohort's bargaining position in China's favour [12]. Finally, the Dutch foreign policy establishment's focus on inclusive policymaking suggests that bargaining boundaries will be more malleable than in, for example, a statist approach [2]. Although this approach is meant to increase responsiveness to domestic voices through intense stakeholder consultation, the resulting practices and expectations increase the effect of shifting bargaining positions on the bargaining space's status quo. Besides bottom-up pressures, the rhetorical strategy behind the B\&R, defined by Nordin and Weissmann as a 'rhetorical trap' ([42]: 241), is expected to reinforce the governments' fears of China swapping the carrot for the economic stick, thereby shrinking the bargaining space.

\section{Reception in the Dutch cohorts}

\footnotetext{
12 While policymaking in the Netherlands characteristically involves issue-specific consultation and the formulation of multistakeholder pacts and strategies for dealing with (foreign) policy issues, the formulation of the China-strategy as the sole countryspecific foreign policy document reflects this insecurity.
} 
Departing from the stated hypotheses, the case study identifies co-optive processes which are initiated or amplified by the B\&R narrative in each cohort, and traces the effects of these processes on the national bargaining space.

\section{The Media Cohort: Stimulating Negative Attention and Self-reflection by Acting as a 'Discursive Lever'}

Discursive analysis of dominant representations of the B\&R in newspaper articles confirmed the expectation that the narrative generates substantial attention due to geopolitical anxiety and its sensational value. The distribution of articles reveals both a gradual increase in interest after the $2017 \mathrm{BRF}$, and the concentration of

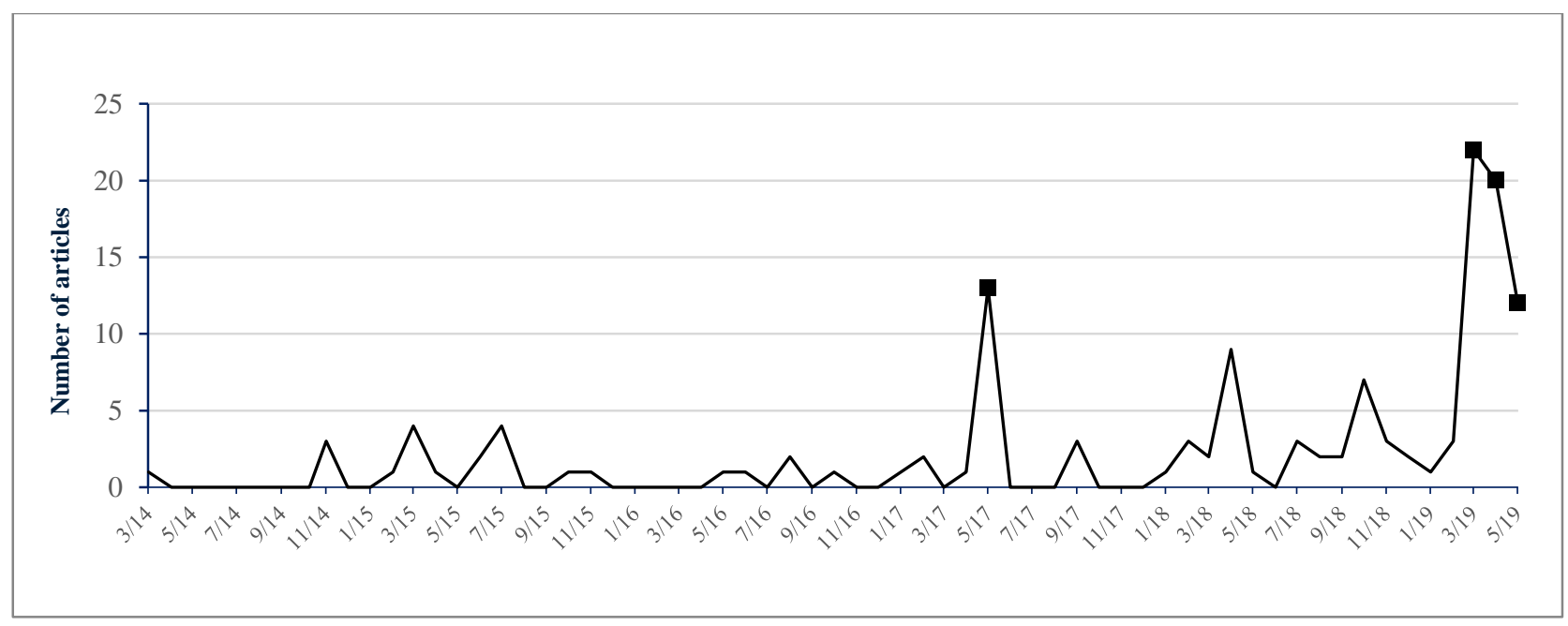

Fig. 1 Number of analysed articles over time per month. Highlighted data points (squares) represent the occurrence of major B\&Rrelated events. In order from left to right these events were: the 2017 BRF; Xi Jinping's visit to Europe and Italy's decision to sign a B\&R MoU; the 2019 BRF; the presentation of the new Dutch China-note. Source: author's own work.

articles around key events with geopolitical or domestic significance (see figure 1). This 'event-driven journalism', which is known to characterize coverage of China more broadly [26], means that reception of the narrative depended greatly on these temporary increases in attention [19]. The media's identity-bound use of the narrative's sensational value in the context of such events is exemplified by frequent repetition of the billion-dollar figures announced by Chinese leaders.

Intriguingly, the analysis only partly confirmed the expectation that the narrative leads to an overwhelmingly negative reception due to a clash between extant and received discourses. Paragraphs or sentences which were coded as negative ( $46 \%$ of words coded) mainly frame the project in the context of 'undue influence', 'a lack of reciprocity', 'the disruption of EU unity', and 'debt trap diplomacy'. Positively coded paragraphs and sentences (36\% of words coded) focus on its 'effects on the Dutch economy', the 'ancient silk road(s)' connection, and the 'Asian Infrastructure Investment Bank' ${ }^{13}$ Intriguingly, there is a notable difference between reporting which takes the Netherlands as its focus and reporting on international politics in general. Whereas articles from the latter category are almost exclusively populated with accounts of geopolitical confrontation and EU/US criticism of the project, domestically-oriented articles bring in a variety of Dutch voices which are less critical. Taking the example of the Port of Rotterdam, a central pillar of the Dutch economy, the latter emphasizes 'China's quest to dominate global transport networks', while the

\footnotetext{
${ }^{13}$ Framing techniques conformed to those identified by Lams in the framing of China in Dutch-language news, and include: us-them dichotomies; stereotyping; generalization; lexical cohesion; and rhetorical devices [25].
} 
former is divided between 'a possible undermining of our competitiveness' and 'opportunities brought about by the B\&R'. This suggests that the dominant truth-claim about the B\&R in the cohort -which can be summarized as China's geopolitical strategy for achieving its goals to the detriment of the EU and the international order-is unable to achieve hegemonic status due to the presence of dissenting discourses. ${ }^{14}$

Taken as a whole, the effects of increased attention and the negative-but-contested interpretation of the narrative on the bargaining space were found to be less unidimensional than predicted. Although reception did arguably increase issue salience, it also produced a co-optive process with two main identifiable functions. Firstly, the penetration of the media ecology by dissenting discourses stimulated societal debate through critical examination of hegemonic truth-claims. For example, during the presentation of the 2019 China-note, Foreign Minister Blok touched on the negativity in the China-debate: "we should base ourselves on facts and knowledge, not feelings and perceptions" [51]. The closing speech by a well-known publicist at a debate about the China-note alluded to a similar sentiment, as he called upon journalists, academics and politicians to examine 'to which extent fear of China originates from a lack of confidence in liberal democracy and the West's capacity to innovate'. ${ }^{15}$ Secondly, the issue's increasing salience possibly drew attention away from human rights issues and frames which have historically commanded the attention of Western readers, to the economic and geopolitical dimensions of China's relationship with the West. The B\&R, while engendering mostly negative responses, thus also acts as a discursive 'lever', which pushes open the door towards partial deconstruction of pre-existing interpretations of China's role in the international system.

\section{The Business Cohort: Reinforcing Existing Beliefs by Acting as an 'Economic Lure'}

The analysis of the second cohort seems to confirm the hypothesis that Dutch business actors are relatively likely to be co-opted, due to strong bilateral economic ties and their tendency to separate business and politics. When asked about the B\&R's non-material dimension, most respondents initially stated that the B\&R was 'just window-dressing'). ${ }^{16}$ However, when asked about relationships and meetings with Chinese counterparts and officials, most respondents admitted they regularly employed 'resurrection of the silk road' and 'win-win cooperation' discourses to maintain and improve relationships. According to some, this tendency increased in recent years concomitant with the increase in visits from Chinese officials, investors and businessmen under the $B \& R$ aegis. This functional internalization of its business-oriented discourses seemingly contradicts the negative framing of the project's economic dimension as serving mainly Chinese interests. In response to this contradiction, most respondents dismissed reports in Western media as 'sensationalistic' or even politicallymotivated, and noted they preferred relying on personal experience (i.e. interaction with Chinese counterparts) and sector-specific industry media. As a result, most viewed the project as a 'global infrastructure investment scheme', as opposed to the 'geopolitical strategy' image which haunted the media ecology. Interestingly, as positive reports in the media ecology often concern opportunities for- and innovations by Dutch business actors, the cohorts' positive engagement with the project may even partially explain the contradiction between reporting on domestic and international issues.

Of particular interest is the finding that the degree to which actors employed such discourses depended more on the wish to expand the business relationship with China in the future than simply maintaining the extant relationship or securing specific contracts in the short term. ${ }^{17}$ This was particularly visible among Small

\footnotetext{
${ }^{14}$ A distinction is made here between dominant, which refers to the relative majority share of a truth-claim in a given situation, and hegemonic, which denotes a situation where meaningful alternative claims are (almost entirely) excluded.

${ }^{15}$ Participant observation at a conference on the China-note in The Hague, June of 2019.

${ }^{16}$ Author's semi-structured interviews with a senior representative of the Port of Rotterdam, phone interview, April 2018; general manager of a Dutch China-based consultancy, phone interview, March 2018; general manager of a transport company active on the trans-Eurasian railroads, phone interview, April, 2018; and informal ad hoc interviews conducted during participant observation.

${ }^{17}$ Examples of this range from functional internalization by a company managing rail freight, to comprehensive internalization and even active proselytization in the case of a China-based consultancy.
} 
and Medium-sized Enterprises (SME's), as their limited access to Chinese business- and policy-making networks meant they felt that mastering the 'discursive vocabulary' was useful to compete for scarce opportunities. Although this functionalist approach to the narrative would suggest it holds little sway over how actors experience the international system, there are signs that respondents did internalize the implicit logics underpinning its business-oriented discourses. For example, all respondents subscribed to ideas like: 'China is investing a lot abroad, unlike the West'; 'it's [China's] economic rise is inevitable' and 'although we may not like its political system, the economic opportunities are undeniable'. While opinions diverged about political and economic issues such as the B\&R's role in Xinjiang and the level playing field, most argued that these were for politicians to solve and 'should not interfere with our ability to conduct business'. In this cohort, the observed function is thus best summarized as an 'economic lure', which increases attention to China and reinforces existing beliefs through economic temptation.

In terms of the national bargaining space, this 'economic lure' co-optive process led business actors to pressure for more government action, and contributed to the establishment and intensification of Chinaoriented public-private networks. Across the board, business actors felt that the government should 'take a clear position' and 'put the Netherlands on the B\&R map to capitalize on new opportunities' [59]. As early as 2016, the Ministry of Foreign Affairs (MFA) and Clingendael (a government-affiliated think-tank) initiated an informal private 'silk road consultation mechanism' (SRCM), which included pillars of the domestic economy like the Port of Rotterdam, members of academia and government officials to 'improve the information position on the B\&R through consultation'. ${ }^{18}$ While the SRCM mainly provided a forum for consultation of large enterprises, the Ministry of Infrastructure and Water Management (MIWM) responded to vocal transportsector SME's in 2017 by enhancing coordination on opportunities along Trans-Eurasian railroads such as the 'Eurasian Land Bridge' [49]. The mutual socialization which happens through such informal consultation on policy-making is illustrated by the discussion about whether to sign a Memorandum of Understanding (MoU) on the B\&R, which occurred during the 2018 Dutch trade mission to China. ${ }^{19}$ Whereas the broad consensus among business actors to intensify engagement with China sent a clear signal to policymakers, the critical stance on the MoU of larger enterprises was arguably partially shaped by inculcation of sensitivities to longterm consequences at venues like the SRCM. The government's decision to hold off on the April $2018 \mathrm{MoU}$ proposed by China, but sign a MoU on 'economic cooperation in third markets' in October shows that this interplay played a role in its evaluation of viable policy directions and thus the bargaining boundaries for the Sino-Dutch relationship.

The influence of these beliefs was particularly visible during the period of intensified stakeholder consultation between late 2018 and May of 2019, which the MFA initiated in cooperation with knowledge institutes and employer consortia to gather input for the formulation of the China-note. Through networking activities and seminars, such as the conference on Chinese investments in which the author participated, representatives of government, business, media and NGO's discussed the requirements of the new China policy. Unsurprisingly given the importance attached to human rights in Dutch politics, the tension between trade and values in the Sino-Dutch relationship was reflected by the stark contrast between the beliefs of business and civil society actors at the conference. In seeking to mediate such divergent beliefs, the organizers presented research which countered assumptions on Chinese investments and exhorted business actors to clearly articulate sensitive (political) issues, such as regarding the 'level playing field'. Confronted with the risks of offending China on one hand and going against societal dogma on the other, business representatives pushed for more private consultation. This risk-averse strategy also motivated employer consortia to use a parliamentary roundtable on foreign trade policy to push for government action to 'secure opportunities in China' and 'improve the level playing field', just a few weeks before the new China policy would be published

\footnotetext{
${ }^{18}$ Author's interviews with a scholar involved in policy consultation, The Hague, August, 2018; a senior representative of the Port of Rotterdam, phone interview, April 2018.

${ }^{19}$ Ibid.
} 
[59]. Broadly speaking, these examples illustrate that the practices and expectations surrounding the country's tradition of stakeholder consultation facilitate the effects of narrative-reinforced beliefs on bargaining boundaries -such as the atrophy of economic decoupling as a policy option-, thus shaping the national bargaining space's status quo.

\section{The Foreign Policy Cohort: the Difficulty in Balancing Policy Pressures in the Face of China's 'Performative Act'}

The narrative was predicted to affect the foreign policy establishment's bargaining position in two ways. On the one hand, it was predicted to be sensitive to bottom-up narrative-induced pressures, due to the importance it attributes to stakeholder consultation in foreign policy-making. The two previous sections illustrated these pressures and provided tentative proof for this hypothesis. By tracing the foreign policy cohort's management of domestic pressures in the context of the formulation of the China-note, this section confirms these findings and highlights the importance of the narrative's strategic ambiguity for avoiding contestation. On the other hand, the narrative was predicted to affect the cohort's by inflating perceptions of the likelihood of retaliation, due to China's signalling of the B\&R's political importance. Although the analysis of the cohort's reception of the narrative and communication about the China-note suggests this is the case, the lack of data about the considerations behind policy choices meant this finding could not be confirmed to a high degree of certainty.

Despite substantial subnational engagement and international media coverage, the B\&R saw little central government attention before early 2018. One respondent interviewed in early 2018 noted that "the idea that China is building new forms of global governance with the $B \& R$ and AIIB, and might be the major power of the first half of the twenty-first century, is almost entirely absent among the broader elites ". ${ }^{20}$ This meant that policy choices like the Netherlands' decision to jointly criticize the B\&R on its standards with twenty-six other EUMS in April 2018, and ministry-level initiatives like the MIWM's efforts at business promotion largely proceeded without coherent central coordination [21]. The sense of confusion regarding the $B \& R$ among even top-level policymakers during this period, exemplified by superficial discursive responses such as 'maintaining an open-minded and pragmatic attitude', suggests that its ambiguity concealed the need for a coherent response [36]. Another argument which supports this notion is the stable consensus among respondents that 'it is not a key message of Chinese public diplomacy in the Netherlands', and that China's soft power activity in the context of the project was aimed towards companies.

Indicating a clear caesura, one respondent noted that "awareness of the strategic considerations behind the Belt and Road Initiative developed substantially throughout the second half of 2018 ". ${ }^{21}$ This shift preceded a broader shift in attention across Dutch media and politics towards China's role in the international system, due to rising geopolitical tensions between the US and China and increased international attention to hot-button issues like China's securitization of Xinjiang and alleged national security risks in the context of Huawei's 5G rollout in Europe. ${ }^{22}$ To illustrate, the number of publicly filed parliamentary motions and questions on China rose from one or two per month throughout 2018, to an average of six per month in the first half of 2019.

The development of the China-strategy, which occurred in this context of heightened scrutiny, illustrates the difficulties experienced by the cohort in renegotiating the bargaining space's status quo vis-à-vis China in the face of domestic pressures. In line with the inclusive approach to foreign policy-making, Minister Blok announced the establishment of an 'interdepartmental working group' for the China-strategy in late 2018 which would 'weigh opportunities and threats in consultation with external stakeholders from business, academia, think-tanks and NGO's' [58]. In April of 2019, it was reported that the negotiations caused substantial friction

\footnotetext{
${ }^{20}$ Author's interview with a China-expert active in policy-circles, phone interview, April 2018.

21 Ibid.

${ }^{22}$ Author's interview with a member of the Parliamentary Commission of Foreign Affairs, The Hague, April 2019.
} 
between the MFA, Ministry of Justice and Security (MJS) and Ministry of Economic Affairs and Climate Policy (MEACP), and that the scope of the strategy would be limited as a consequence [40]. Whereas the MJS was said to be unwilling to compromise on security concerns, which became salient due to negative reporting on Huawei in the media, the MEACP pushed for further economic engagement. The MFA for its part was mainly concerned with diplomatic fallout if the country were to adopt a 'tough stance' on China. Given the complexity of resolving such contradicting interests within a short span of time, it was perhaps unsurprising that the main critique of the document -rebranded as a 'note' just before its release- was that it did not present concrete policy choices [58]..$^{23}$

The MFA's careful stance suggests that besides opposing domestic pressures, the image of a dismayed China also loomed large in The Hague. The fact that Minister Blok saw the need to explain the strategy to Chinese counterparts on multiple state visits, in combination with his remarks on the need for objectivity in reporting about China, points to attempts to signal the country's amicability to China [51]. This is further reinforced by the observation that controversial issues, such as economic espionage and industrial policy, are only touched on superficially or by referring to 'country-neutral' policy documents such as the MJS's 'Countering State-based Threats' paper and the 'European Competitiveness' paper of the MEACP and MFA [50].

These choices, together with the seemingly contradictory approach to the $\mathrm{B} \& \mathrm{R}$ laid out in the China-note show that the narrative may have played a role in reinforcing existing fears of retaliation. On the one hand, the document recognized the $B \& R$ as an ideological and material vehicle for realizing the Community of Shared Future and adjusting the international order. In terms of policy responses, the document proposes adherence to the EU's 'Connecting Europe and Asia' strategy to 'improve standards', and stresses the need to develop relationships with the 'community of likeminded states' to counter Chinese attempts to insert B\&R language in UN documents [35]. On the other hand, it contains no overt criticism of the project, and even reflects the MIWM's and MEACP's business cohort-induced push for more economic engagement. It thus implicitly reinforces the core function of the B\&R as a discursive network-strategy. This shows that China's strategy of increasing the cost of discursively contesting the $B \& R$ allows it to limit the damage to the legitimacy of its geopolitical and geo-economic 'going out' (走出去). Viewed in this way, its effects on the cohort may be summarized as a 'performative act', whereby China integrates displays of magnanimity and openness (i.e. building much-needed infrastructure and signalling willingness to listen to others) into its traditional carrot and stick (羁縻) approach [27].

\section{Conclusion}

This article has argued that the expectation of autonomous national decision-making vis-à-vis China, which is based on Eurocentric arguments about its (in)ability to co-opt others, does not hold up in the face of the observed effects of the B\&R strategic narrative in the critical case of the Netherlands. On the contrary, it illustrated that the narrative's reception in different subnational cohorts tilted important elements of the bargaining game to China's favour. The B\&R was thus found to conform to the expectations of Chinese elites to improve China's discursive position abroad, with clear variations between different audiences depending on their identities and ability to affect change. The narrative was arguably most successful among business actors, where it's function as an economic lure not only produced pressure for amicable economic engagement with China, but also discourses which went on to contest dominant truth-claims in the media ecology. Furthermore, China's use of ostentatious displays of wealth and power through the BRF and headline-worthy investment figures ostensibly contributed to the rise in attention to its story, and -together with a general rise

\footnotetext{
${ }^{23}$ The adoption of a parliamentary motion requiring the MFA to rewrite the 'values' chapter of the strategy in September of 2019 illustrated that the polarization of bargaining positions did not dissipate after the strategy's publication, but rather intensified.
} 
in attention to China across Dutch society- were found to have engendered a China-debate wherein critical responses to preconceived notions about the country are given greater voice. Finally, the available evidence suggests that the narrative not only created pressures for continued economic engagement from below but also at the bilateral level, as it reinforced historically-induced fears of economic loss through an application of rhetorical strategy. In spite of the fact that the influence provided by the narrative is limited, the main relevance of these findings is that this form of co-optation proved viable in a critical case with little in the way of concrete investments or active public diplomacy.

In search of a mechanism which explains these co-optive functions, the narrative's appeal to the material interests of actors -referring to its sensational value, its value as a talking-point among business partners, or as a rhetorical carrot/stick-hybrid- was found to play a large role in the continued exposure of actors to the narrative and the subsequent inculcation of some of its implicit logics. This calls into question the valuedisparity argument from the traditional soft power literature, a major theoretical foundation for practices of public diplomacy in the West. Furthermore, the role of the expectation of future economic gain poses the question to what extent economic inducement can be relegated to the domain of hard power. Based on the findings, the view taken here is that discursive engagement only transforms into hard power when the narrating actor attaches specific economic consequences (such as the erection of tariff barriers) to behavioural change, which leaves economic temptation squarely in the domain of soft power [30].

Taking this continued-exposure mechanism as an example, the case study demonstrates that the Foucauldian interpretation of discourse embodied by strategic narrative theory and the networked understanding of discursive engagement and decision-making enabled by the bargaining space concept produces fine-grained inferences about soft power success, which are grounded in systematic observation. This suggests that constructivist efforts to improve soft power analyses through theoretical and methodological innovation, particularly the integration of inductive reasoning and a move away from the comfortable abstractions of system level rationalist theory, may yield valuable insights into an international system increasingly characterized by the 'weaponization' of political discourse. The bargaining space concept in particular provides convincing tools for tracing which, and especially how, actors mattered in a complex context, which enhances the credence of inferences about power effectiveness beyond the degree normally accorded to constructivist soft power approaches. Besides its utility, the concept is also highly fungible, as it can be conveniently mapped onto approaches other than strategic narrative theory. One caveat against the framework's application lies in its effectiveness outside uniquely transparent cases such as the Dutch one, wherein actors and their bargaining positions are relatively easily identified.

The weak generalizability accorded to single case studies represents the main weakness of this study, especially in the context of China's growing role in EU politics [11]. In the interest of identifying implications for the EU, limited generalization is possible through the method of layered generalization, whereby scope conditions of the critical case are gradually removed to enable predictions about a broader set of EUMS [52]. Given the openness of Western European societies and the similarity of their media ecologies, it is likely that many functions of the $B \& R$ narrative, including the inculcation of its implicit logics would still occur. However, the statist approach which countries like France and Belgium espouse towards foreign policymaking arguably limits the translation of these effects into their China policies. Going further, the nature of the narrative's impact on the bilateral level likely depends on countries' particular historical experiences with China.

One obvious area for further study would be to conduct similar case studies of other countries, especially other European member states. Doing so would not only enable comparison of the narrative's effects across cohorts and countries, but also a more complete picture of how the narrative affects the EU and its China policy. Moving beyond the $\mathrm{B} \& \mathrm{R}$, the developed approach can be applied on all levels of analysis where actors use narratives to affect collective decision-making. 


\section{References:}

1. Adviesraad Internationale Vraagstukken. 2019. China en de strategische opdracht voor Nederland in Europa [China, and the Netherlands' strategic mission in Europe], 15 June 2019. Retrieved from https://aiv-advies.nl/9yx\#advice-summary. Accessed 28 June 2019.

2. Arts, G., Y. Kleistra, M. Klem, B. Knapen, and M. Rem, eds. 2011. Attached to the World: On the Anchoring and Strategy of Dutch Foreign Policy. Amsterdam: Amsterdam University Press.

3. American Enterprise Institute. 2019. China Global Investment Tracker, 10 July 2019. Retrieved from https://www.aei.org/chinaglobal-investment-tracker/. Accessed 12 July 2019.

4. Beeson, M. 2018. Geoeconomics with Chinese characteristics: the BRI and China's evolving grand strategy. Economic and Political Studies 6 (3): 240-256.

5. Blanchard, J. F., and F. Lu. 2012. Thinking Hard About Soft Power: A Review and Critique of the Literature on China and Soft Power. Asian Perspective 36(4): 565-589.

6. Brown, K. 2019. China's 19th Party Congress: start of a new era. New Jersey: World Scientific.

7. Casarini, N. 2016. When All Roads Lead to Beijing. Assessing China's New Silk Road and its Implications for Europe. The International Spectator 51 (4): 95-108.

8. Cho, Y.C., and Y. Hwang. 2019. Mainstream IR Theoretical Perspectives and Rising China Vis-À-Vis the West: The Logic of Conquest, Conversion and Socialisation. Journal of Chinese Political Science, advance online publication 13 April, doi: 10.1007/s11366-019-09620-3.

9. d'Hooghe, I. 2015. China's Public Diplomacy. Leiden: Brill Nijhoff.

10. Ding, S. 2008. The dragon's hidden wings: how China rises with its soft power. Lanham: Lexington.

11. European Commission. 2019. Joint Communication to the European Parliament, the European Council and the Council: EUChina - A strategic outlook, 12 March 2019. Retrieved from https://ec.europa.eu/commission/news/eu-china-strategic-outlook2019-mar-12_en. Accessed 13 March 2019.

12. European Think-tank Network on China. 2018. Political values in Europe-China relations, 6 December 2018. Retrieved from https://www.merics.org/en/political-values-in-europe-china-relations. Accessed 6 December 2018.

13. Fan, Z., and J. Zhou. 2016. Yidai Yilu Zhanlüe Beijing Xia De Zhongguo Wenhua Ruanshili Jianshe Yanjiu [Research on the Development of Chinese Cultural Soft Power in the Context of the Belt and Road Strategy], Tongji Daxue Xuebao [Journal of Tongji University] 27 (5): 40-47.

14. Feklyunina, V. 2016. Soft power and identity: Russia, Ukraine and the 'Russian world(s)'. European Journal of International Relations 22 (4): 773-796.

15. Feng, A., A. Kratz, and O. Wright. 2019. New Data on the "Debt Trap" Question. Rhodium Group, 29 April 2019. Retrieved from https://rhg.com/research/new-data-on-the-debt-trap-question/. Accessed 4 July 2019.

16. Gallarotti, G. M. 2011. Soft power: what it is, why it's important, and the conditions for its effective use. Journal of Political Power 4 (1): 25-47.

17. George, A. L., and Bennett, A. 2005. Case Studies and Theory Development in the Social Sciences. Cambridge (Mass.): MIT Press.

18. Gill, B., and Y. Huang. 2006. Sources and limits of Chinese "soft power." Survival 48 (2): 17-36.

19. Guo, R., and X. Guo. 2019. Huayu, Gushi, Yu Zhanlüe Dingli. Guanyu "Yidai Yilu” Changyi Duiwai Chuanbo De Ji Dian Sikao [Discourse, Stories and Strategic Anchoring. Reflections on External Propaganda and the Belt and Road Initiative]. Duiwai Chuanbo [International Communications] 5 (5): 55-57.

20. Hall, T. 2010. An Unclear Attraction: A Critical Examination of Soft Power as an Analytical Category. Chinese Journal of International Politics 3 (2): 189-211.

21. Heide, D., T. Hoppe, S. Scheuer, and K. Stratmann. 2018. EU ambassadors band together against Silk Road, Handelsblatt, 17 April 2018. Retrieved from https://www.handelsblatt.com/today/politics/china-first-eu-ambassadors-band-together-against-silkroad/23581860.html. Accessed 4 July 2019.

22. Hayden, C. 2017. Scope, Mechanism, and Outcome: Arguing Soft Power in the Context of Public Diplomacy. Journal of International Relations and Development 20 (2): 331-357.

23. Holslag, J. 2017. How China's New Silk Road Threatens European Trade. The International Spectator 52 (1): $46-60$.

24. Huang, Y. 2016. Understanding China's Belt \& Road Initiative: Motivation, framework and assessment. China Economic Review 40: 314-321.

25. Jakimów, M. 2019. Desecuritisation as a soft power strategy: the Belt and Road Initiative, European fragmentation and China's normative influence in Central-Eastern Europe. Asia Europe Journal, advance online publication 13 September, doi:10.1007/s10308-019-00561-3.

26. Lams, L. 2016. China: Economic magnet or rival? Framing of China in the Dutch- and French-language elite press in Belgium and the Netherlands. International Communication Gazette 78 (1-2): 137-156.

27. Lams, L. 2018. Examining Strategic Narratives in Chinese Official Discourse under Xi Jinping. Journal of Chinese Political Science 23 (3): 1-25. 
28. Lee, P.S. 2016. The rise of China and its contest for discursive power. Global Media and China 1 (1-2): 102-120.

29. Li, M., ed. 2011. Soft power: China's emerging strategy in international politics. Lanham: Lexington.

30. Li, X., and V. Worm. 2011. Building China's Soft Power for a Peaceful Rise. Journal of Chinese Political Science, 16 (1): 69 89.

31. Mattern, J.B. 2005. Why 'Soft Power' Isn't So Soft: Representational Force and the Sociolinguistic Construction of Attraction in World Politics. Millennium 33 (3): 583-612.

32. Mayer, M. 2018. China's historical statecraft and the return of history. International Affairs 94 (6): 1217-1235

33. Mazarr, M.J., A. Casey, A. Demus, S.W. Harold, L.J. Matthews, N. Beauchamp-Mustafaga, and J. Sladden. 2019. Hostile Social Manipulation: Present Realities and Emerging Trends. Santa Monica, CA: RAND Corporation.

34. Minghao, Z. 2016. The Belt and Road Initiative and its Implications for China-Europe Relations. The International Spectator 51 (4): 109-118.

35. Ministerie van Buitenlandse Zaken. 2019. Nederland-China: een nieuwe balans [Netherlands-China: a new balance], 15 November 2019. Retrieved from https://www.rijksoverheid.nl/documenten/rapporten/2019/05/15/nederland-china-een-nieuwebalans. Accessed 15 May 2018.

36. Miskimmon, A., B. O’Loughlin, and L. Roselle. 2013. Strategic narratives : communication power and the new world order. New York; London: Routledge, Taylor \& Francis Group.

37. Miskimmon, A., B. O'Loughlin, and L. Roselle, eds. 2017. Forging the world: strategic narratives and international relations. Ann Arbor: University of Michigan Press.

38. Moramudali, U. 2019. Is Sri Lanka Really a Victim of China's 'Debt Trap'?, The Diplomat, 14 May 2019, https://thediplomat.com/2019/05/is-sri-lanka-really-a-victim-of-chinas-debt-trap/. Accessed 4 July 2019.

39. National Development and Reform Commission. 2015. Visions and Actions on Jointly Building Silk Road Economic Belt and 21st-Century Maritime Silk Road, 28 March 2015. Retrieved from http://en.ndrc.gov.cn/newsrelease/201503 /t20150330_669367.html. Accessed 12 February 2018.

40. Nederlandse Omroep Stichting. 2019. Kabinet worstelt met vraagstuk 'hoe om te gaan met China?' [Government struggles with question on 'how to deal with China?'], NOS, 5 April 2019. Retrieved from https://nos.n1/artikel/2279076-kabinet-worstelt-metvraagstuk-hoe-om-te-gaan-met-china.html. Accessed 5 April 2019.

41. Office of the Leading Group for Promoting the Belt and Road Initiative. 2019. The Belt and Road Initiative: Progress, Contributions and Prospects, 22 April 2019. Retrieved from http://www.xinhuanet.com/english/2019-04/22/c 137998357.htm. Accessed 23 April 2019.

42. Nordin, A.H.M., and M. Weissmann. 2018. Will Trump make China great again? The belt and road initiative and international order. International Affairs, 94 (2), 231-249.

43. Nye, J. S. 2004. Soft power: the Means to Success in World Politics. New York: Public Affairs.

44. Nye, J. S. 2011. The Future of Power (1st ed). New York: Public Affairs.

45. Pacheco Pardo, R. 2018. Europe's financial security and Chinese economic statecraft: the case of the Belt and Road Initiative. Asia Europe Journal 16 (3): 237-250.

46. Pan, S., and J.T. Lo. 2017. Re-conceptualizing China's rise as a global power: a neo-tributary perspective. The Pacific Review 30 (1): 1-25.

47. Pan, Z. 2012. Conceptual gaps in China-EU relations: global governance, human rights and strategic partnerships. Basingstoke: Palgrave Macmillan.

48. Putz, C. 2019. Which Countries Are For or Against China's Xinjiang Policies?, The Diplomat, 15 July 2019. Retrieved from https://thediplomat.com/2019/07/which-countries-are-for-or-against-chinas-xinjiang-policies/. Accessed 17 July 2019.

49. Rijksoverheid. 2019a. Op spoormissie in China [On a rail-mission to China], 16 April 2019. Retrieved from https://www.rijksoverheid.nl/actueel/nieuws/2019/04/16/op-spoormissie-in-china. Accessed 5 July 2019.

50. Rijksoverheid. 2019b. Kamerbrief over strategie Nederland ten opzichte van China [Letter to Parliament concerning the Netherlands' Strategy for China], 15 May 2019. Retrieved from https://www.rijksoverheid.nl/documenten/kamerstukken/2019 /05/15/kamerbrief-inzake-chinastrategie-nederland---china-een-nieuwe-balans. Accessed 16 May 2019.

51. Rijksoverheid. 2019c. Toespraak minister Blok over de China-strategie van het kabinet [Minister Blok's speech about the administration's China-strategy], 15 May 2019. Retrieved from https://www.rijksoverheid.nl/documenten/toespraken/2019 /05/15/toespraak-minister-blok-over-de-chinastrategie-van-het-kabinet. Accessed 16 May 2019.

52. Rohlfing, I. 2012. Case Studies and Causal Inference: an Integrative Framework. Basingstoke: Palgrave Macmillan.

53. Roselle, L., A. Miskimmon, and B. O'Loughlin. 2014. Strategic narrative: A new means to understand soft power. Media, War \& Conflict 7 (1): 70-84.

54. Schöne, H. 2003. Die teilnemende Beobachtung als Datenerhebungsmethode in der Politikwissenschaft. Methologische Reflexion und Werkstattbericht, Forum: Qualitative Sozialforschung 4 (2).

55. Sparks, C. 2018. China's soft power from the BRICS to the BRI. Global Media and China 3 (2): 92-99.

56. Summers, T. 2016. China's 'New Silk Roads': sub-national regions and networks of global political economy. Third World Quarterly 37 (9): 1628-1643.

57. Turcsanyi, R. 2017. Assessing the Power of China: Insights from the Conceptual Thinking about Power. Journal of Chinese Political Science 22 (3): 473-486. 
58. Tweede Kamer der Staten-Generaal. 2018. Beantwoording feitelijke vragen begroting Buitenlandse Zaken 2019 [Response to factual queries about the 2019 Foreign Affairs budget], 2 November 2018. Retrieved from https://www.rijksoverheid.nl /documenten/kamerstukken/2018/11/02/beantwoording-feitelijke-vragen-begroting-buitenlandse-zaken-2019. Accessed 4 July 2019.

59. Tweede Kamer der Staten-Generaal. 2019. Rondetafelgesprek nieuwe kansen en handelspartners [Roundtable on new opportunities and trade partners], 4 June 2019. Retrieved from https://www.tweedekamer.nl/debat_en_vergadering /commissievergaderingen/details?id=2019A01210. Accessed 7 June 2019.

60. Vangeli, A. 2018. Global China and Symbolic Power: The Case of $16+1$ Cooperation. Journal Of Contemporary China, 27 (113): 674-687.

61. Veldkamp, J. 2019. Waarom de nieuwe China-strategie van Nederland geen strategie is [Why the Netherlands' new Chinastrategy is not a strategy], De Correspondent, 17 May 2019. Retrieved from https://decorrespondent.nl/9510/waarom-de-nieuwechina-strategie-van-nederland-geen-strategie-is/137128855380-b5d74cfd. Accessed 4 July 2019.

62. Walker, C., and J. Ludwig. 2017. The Meaning of Sharp Power: How Authoritarian States Project Influence. Foreign Affairs, 16 November 2017. Retrieved from https://www.foreignaffairs.com/articles/china/2017-11-16/meaning-sharp-power. Accessed July 42019.

63. Wendt, A. 1999. Social theory of international politics. Cambridge: Cambridge University press.

64. Wilson, J.L. 2015. Russia and China Respond to Soft Power: Interpretation and Re-adaptation of a Western Construct. Politics, 35 (3-4): 287-300.

65. Xi, J. 2013. Yanlun Fangmian Yao Gan Zhua Gan Guan Ganyu Liangjian [Regarding Public Opinion, We Must Dare to Grasp, Dare to Manage, and Dare to Bare the Sword]. Speech to the National Propaganda and Ideology Work Conference. Beijing, August 192013.

66. Xi, J. 2017a. Work together to Build the Silk Road Economic Belt and The $21^{\text {st }}$ Century Maritime Silk Road. Speech to the opening ceremony of the Belt and Road Forum for International Cooperation. Beijing, May 152017.

67. Xi, J. 2017b. Juesheng Quanmian Jiancheng Xiaokangshehui, Duoqu Xinshidai Zhongguo Tese Shehuizhuyi Weida Shengli [Decisively and Comprehensively Construct the Moderately Prosperous Society, Seize an Important Victory for Socialism with Chinese Characteristics]. Speech to the Nineteenth National Congress of the Communist Party of China. Beijing, October 27 2017.

68. Yang, X. 2017. The Anachronism of a China Socialized: Why Engagement Is Not All It's Cracked Up to Be. The Chinese Journal of International Politics 10 (1): 67-94.

69. Yin, R.K. 2003. Case study research: design and methods (3rd ed.). Thousand Oaks: Sage.

70. Yu, H. 2017. Motivation behind China's “One Belt, One Road” Initiatives and Establishment of the Asian Infrastructure Investment Bank. Journal of Contemporary China 26 (105): 353-368.

71. Zeneli, V. 2019. Italy Signs on to Belt and Road Initiative: EU-China Relations at Crossroads?, The Diplomat, 3 April 2019. Retrieved from https://thediplomat.com/2019/04/italy-signs-on-to-belt-and-road-initiative-eu-china-relations-at-crossroads/. Accessed 4 July 2019.

72. Zeng, J. 2017. Does Europe Matter? The Role of Europe in Chinese Narratives of 'One Belt One Road' and 'New Type of Great Power Relations'. Journal of Common Market Studies 55 (5): 1162-1176.

73. Zeng, J. 2019. Narrating China's belt and road initiative. Global Policy 10 (2): 207-216.

74. Zhao, K. 2016. China's Rise and its Discursive Power Strategy. Chinese Political Science Review 1 (3): 539-564.

75. Zhou, W., and M. Esteban. 2018. Beyond Balancing: China's approach towards the Belt and Road Initiative. Journal of Contemporary China 27 (112): 487-501. 


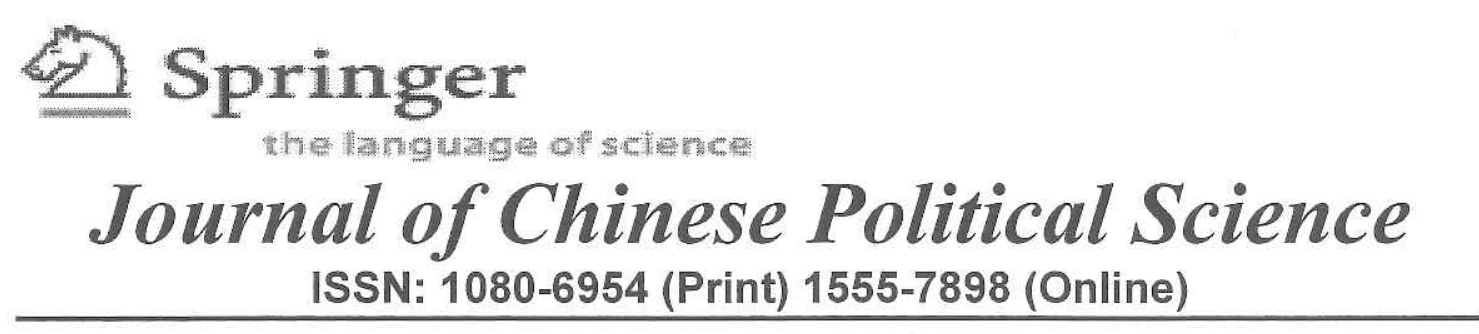

\section{Editorial Agreement}

Manuscript submitted:

Title: Discourse Power as a Means to 'Struggle for Position': a Critical Case Study of the Belt and Road Narrative's Effects on Foreign Policy Formulation in The Netherlands Author: LANGENDONK, Steven

The author warrants, by signing this statement of intention, that the manuscript submitted to the Journal of Chinese Political Science is prepared exclusively for the journal and has not submitted and will not submit to another journal for consideration.

Signature of the author (s):

Name (Print) LANGENDONK, Steven

Institution KU Leuven Faculty of Social Sciences, Department of Political Science, Leuven International and European Studies (LINES)

Date 30 August, 2019

PLEASE SCAN THE SIGNED COPY AND INCLUDE IT IN YOUR SUBMISSION BY UPLOADING IT TOGETHER WITH YOUR "BIOGRAPHICAL STATEMENT". 
Author Biography:

Steven Langendonk is a doctoral researcher at Leuven International and European Studies (LINES), KU Leuven. His research interests cover the intersection between ideology and foreign policy, noncoercive forms of power, Chinese diplomatic practice, and Eurocentric biases in international relations literature, theory and methodology, particularly in the context of China's rise within international relations and organizations. 